catecholamine sensitivity of the strip suggests that the vasoactive substance was itself a catecholamine ${ }^{2}$.

Cyproheptadine $\theta^{3}$ (an anti-histamine and an anti-5-HT agent) decreased greatly the response of the aortic strip to added 5-HT, and abolished the response to added histamino. There was no detectable change in the response to added noradrenaline or to the vasoactive matorial.

Observations on a rat fundal strip and on an isolated guinea pig ileum indicated that tyramine does not release $\tilde{5}$-HT or histamine in amounts adequate to stimulate the spiral aortic strip. The observations on the guinea pig ileum also suggested that a vasoactive polypeptide, for example bradykinin, was not responsible.

It was concluded that the vasoactive material was almost certainly a catecholamine released from the tissue 'stores' of the atrium by tyramino.

W. J. HALL

J. D. SHEEHAN

Department of Physiology, University College, Cork.

${ }^{1}$ Burn, J. H., and Rand, M. J., J. Physiol., 144, 314 (1958).

'Furehgott, R. F., J. Pharmacol., 111, 265 (1954).

${ }^{3}$ Stone, C. A., Wenger, H. C., Ludden, C. T., Stavorski, J. M., and Ross, A. C., J. Pharmacol., 13i, 73 (1961).

\section{Antiserum Inhibition of the Estrous Cycle in Normal Rats}

Evidence for the neutralization of pituitary gonadotrophic hormone activity in mammals by immunological procedures has been reviewed in several articles. The specificity of the hormone neutralizing (antihormone) effect of the antiserum has been suggested by many of the investigations reviewed, but there has been some question as to the specificity of this effect, because of the possible role of impurities or trace antigenic contaminants in the hormone preparations used ${ }^{1-4}$. A recent report ${ }^{5}$ describes the successful inactivation of a purified pituitary folliclestimulating hormone (FSH); the marked follicular stimulation obtained by the injection of sheep FSH into immature hypophysectomized female rats could be completely inhibited with rabbit antiserum to the homologous FSH. This inhibitory effect was found to be dependent on the dosage of antiserum used. Other recent studies have reported the neutralization of endogenously secreted pituitary intorstitial-cell stimulating hormone (ICSH) in the normal immature ${ }^{6-8}$ and mature ${ }^{8}$ male rat and in the immature female rat ${ }^{9}$, with the use of antiserum prepared against purified sheep ICSH.

This is a preliminary report showing that rabbit antiserum to purified sheөp ICSH can inhibit the œstrous cycle in adult female rats. Supporting evidence is presented to indicate the spocificity of the observed antihormone effect. A detailed report of the inhibition (with the same antiserum) of testicular dovelopmont and maturation in tho normal male rat is now awaiting publication ${ }^{10}$.

Antiserum was prepared by a method previously described ${ }^{8}$. Young albino male rabbits wore immunized by injecting them subcutanoously with purified sheep ICSH (N.I.H.- $L H-S 1$, received through the courtesy of the Endocrine Study Section of the National Institutes of Health: this preparation has been fully characterized; the assay data have boen presented elsewhere ${ }^{10}$ ) in Freund's adjuvant, over a period of 3-5 months (total doso of 4-6 $\mathrm{mg}$ por animal). The last injection $(0.25 \mathrm{mg})$ was given in saline 8-10 days prior to bleeding. The antiserum was absorbed to removo non-spocific antibodies a.gainst homologous (sheep) sorum protoins.

Before antiserum treatmont was started, the vaginal cycling patterns of adult female Long-Evans rats wero followod for a period of 16 days. Animals were selected for the experiment on the basis of a normal 4-5 day eycling pattern, as determined by examination of their vaginal smears (stained with Giemsa). The antiserum injections were given in gradually increasing dosages $(0.5 \mathrm{ml}$. to $3.0 \mathrm{ml}$. per day) over an 11-day period, with an average daily doso of approximately $1.5 \mathrm{ml}$. All antiserum-injected rats showed sustained diostrus vaginal smears after the socond or third day of treatment. Regardless of the particular phase of the vaginal cycle in which the animal happenod to be at the time that the injections were commenced, the antiserum administration resulted in a complete cessation of cycling, stopping it in the same phase in all animals. The vaginal cycling of animals treated with normal rabbit serum (NRS) showod no significant differences from that of the non-treated control animals. It was of interest to note that the antisorum-injocted animals eommonced to cycle again approximately 10 days after treatment had been discontinued. Histological examination of the ovaries of antiserum-treated rats revealed that the interstitial cells wore as deficient in appearance as those in hypophysectomizod animals. The recovery of normal vaginal cycling was accompanied by a restoration of the appearance of these cells to normal.

Rats in one of the antisorum-treated groups were injected $24 \mathrm{~h}$ before death with $\mathrm{I} \mu \mathrm{c}$. of iodine-131 to determine the effect of antiscrum treatment on thyroid function. It was found that the uptake of iodine-131 by the thyroid glands from the antiserum-injected rats was not significantly different from that for animals injected with NRS. This finding suggested that the ICSH antiserum did not contain antibodies against thyroid-stimulating hormone, as demonstrable by this method.

There was no evidence to indicate toxicity of the antiserum, as judged by the lack of effect on gain in bodyweight and adrenal or thymic weights. If anything, the antiserum administration resulted in a slight but definite increase in body-weight gain. The foregoing findings suggested that the antiserum did not contain any dotectable antibodies against rat pituitary growth hormone or adrenocorticotrophic hormone. Still another test which indicated the specificity of the antihormone effect was the observation of precipitin reactions in agar diffusion plates $^{11}$. Using a technique previously described ${ }^{12}$, it was found that the minimum detectable amount of the homologous hormone (sheep ICSH, N.I.H. $-L H-S 1$ ) was of the order of $2 \mu \mathrm{g}$, yet the samo antiserum did not give a positive precipitin reaction with varying doses $(2-200 \mu \mathrm{g})$ of any of the other known antorior pituitary hormones in highly purified form. All hormones had been obtained from the homologous (sheep) species except for thyroidstimulating hormone which was bovine in origin. The results of the various tests mentioned here strongly suggested that the antihormone effect of the antiserum may be dependent on a specific antigen-antibody intoraction. A detailed report of theso studies in fomale rats will be presented elsewhere.

This work was supportod in part by grants $(A-3350$ and $G M-K 3-6710-C 3)$ from the National Institutes of Health of the U.S. Public Health Servico.

\section{W. P. Young \\ R. NASSER \\ T. HaYashida}

Dopartment of Anatomy,

Univorsity of California Medical Center, San Francisco 22.

${ }^{1}$ Thompson, K. W., Physiol. Rev., 21, 588 (1941).

2 Ieathem, J. H., Recent Progress in Hormone Research, 4, 135 (1949).

3 Bussard, A., J. Physiol. Path. Gén., 44, 717 (1952).

"Werth, G., Arzneimittel-Forsch., 6, 87 (1956).

'Hayashida, 'T., and Chino, S., Anat. Rec., 139, 236 (1961).

${ }^{6}$ Moudgal, N. R., and T., C. II., Arch. Biochem. Biophys., 95, 93 (1961).

7 Hayashida, T., in Ciba Found. Coll. Endocrinol., 14, 326 (1962).

${ }^{8}$ Hayashida, T., Anat. Ree., 142, 308 (1962).

'Bourdel, G., Gen. Compar. Endocrinol., 1, 375 (1961).

${ }^{10}$ Hayashida, 'T., J. Endocrinol. (in the press).

$"$ Ouchterlony, O., Acta Pathol. Microbiol. Scand., 32, 231 (1953).

${ }^{12}$ Hayashida, T., and Li, C. H., Endocrinol., 65, 944 (1959). 